\title{
PENGARUH LINGKUNGAN KERJA FISIK DAN KOMUNIKASI TERHADAP SEMANGAT KERJA KARYAWAN PADA PT BALI MAYA PERMAI NEGARA JEMBRANA
}

\author{
Nur Baity Jannah ${ }^{1}$, I Nyoman Sujana ${ }^{2}$, Anjuman Zukhri ${ }^{3}$ \\ Jurusan Pendidikan Ekonomi \\ Universitas Pendidikan Ganesha \\ Singaraja, Indonesia \\ e-mail: baity.eti@yahoo.com ${ }^{1}$ sujanatbn@yahoo.com ${ }^{2}$, \\ anjumazukhri09@gmail.com ${ }^{3}$
}

\begin{abstract}
Abstrak
Penelitian ini bertujuan untuk mengetahui pengaruh lingkungan kerja fisik dan komunikasi terhadap semangat kerja karyawan PT. Bali Maya Permai Negara-Jembrana baik secara parsial maupun simultan. Jenis penelitian ini merupakan penelitian kausal. Data dikumpulkan dengan metode kuisioner dan dokumentasi. Populasi yang digunakan dalam penelitian ini adalah seluruh karyawan di PT.Bali Maya Permai Negara yaitu sebanyak 55 orang. Teknik analisis data menggunakan metode analisis regresi linier berganda menggunakan program komputer software SPSS 16.0 for Windows. Hasil penelitian menunjukkan bahwa lingkungan kerja fisik berpengaruh signifikan terhadap semangat kerja karyawan ditunjukkan dari nilai thitung $>\mathrm{t}$ tabel $(6,447>02609)$, komunikasi karyawan perpengaruh signifikan terhadap semangat kerja ditunjukkan dari nilai $t_{\text {hitung }}=2,448>t_{\text {tabel }}=0.609$, lingkungan kerja fisik dan komunikasi berpengaruh terhadap semangat kerja karyawan ditunjukkan dari Fhitung $>$ Ftabel $(48,516>3,22)$.

Kata Kunci : lingkungan kerja fisik, komunikasi dan semangat kerja

Abstract

This study aims to determine the influence of physical work environment and communication to employee morale PT.Bali Maya Permai State-Jembrana either partially or simultaneously. This type of research is a causal study. Data were collected by questionnaire and documentation method. The population used in this research is all employees in PT.Bali Maya Permai Negara that is as much as 55 people. Data analysis techniques using multiple linier regression analysis method using computer software program SPSS 16.0 for Windows. The results showed that the physical work environment has a significant effect on employee morale is shown from the value of $t$ test $>t$ table $(6,447>02609)$, employee communication significant to the morale is shown from the value $\mathrm{t}$ test $=2.448>$ ttable $=0.609$, physical and communication work environment influential to employee morale is shown from Fcount> Ftable $(48,516>3,22)$.
\end{abstract}

\section{PENDAHULUAN}

Keywords: physical work environment, communication and morale

Dalam menghadapi persaingan yang semakin ketat, sangat diperlukan adannya sumber daya manusia yang berkualitas sehingga mampu menghadapi persaingan dan perubahan. Lingkungan yang dihadapi oleh manajemen sumber daya manusia sangat menantang karena perubahan muncul sangat cepat dan memiliki masalah yang luas. Dalam menghadapi kondisi tersebut, sebuah perusahaan dituntut untuk selalu menyesuaikan diri terhadap segala perubahan yang terjadi agar dapat bertahan dalam persaingan.

Tujuan akan dapat tercapai jika sumber daya yang menggerakkan perusahaaan tersebut memiliki semangat kerja yang tinggi. Semangat kerja yang tinggi membuat karyawan yang bersungguh- sungguh dalam melaksanakan dan menyesaikan segala 
tugasnya, sehingga dapat memudahkan tercapainya segala tujuan perusahaan. Sumber daya manusia merupakan faktor yang sangat sentral dalam perusahaan. Apapun bentuk dan tujuannya,perusahaan dibuat berdasarkan berbagai visi untuk kepentingan manusia. Begitu pula dalam pelaksanaan misinya maka dikelola dan diurus oleh manusia. Dengan demikian manusia merupakan faktor yang sangat strategis dalam semua kegiatan perusahaan. Agar dapat mengatur dan mengurus sumber daya manusia berdasarkan visi perusahaan sehingga tujuan perusahan tercapai maka dibutuhkan ilmu, metoda dan pendekatan pengelolaan sumber daya manusia atau yang sering disebut dengan manajemen sumber daya manusia. Ini berarti bahwa manajemen sumber daya manusia juga menjadi bagian dari ilmu manajemen (management science) yang mengacu kepada fungsi manajemen yang dalam pelaksanaannya meliputi proses-proses perencanaan, pengorganisasian, staffing, memimpin dan mengendalikan. Peran sumber daya manusia dari waktu ke waktu akan semakin strategis terhadap perkembangan dan dinamika perusahaan. Agar perusahaan mampu bertahan di dalam menghadapi persaingan adalah adanya kemampuan untuk meningkatkan produktivitas sesuai dengan pesanan. Produktivitas hanya dapat dicapai apabila perusahaan tersebut melalui pimpinan mampu mensinkronkan antara kepentingan pegawai dengan kepentingan perusahaan. Karena pegawai bekerja pada suatu perusahaan dengan motivasi yang berbeda-beda. Oleh karena itu diperlukan adanya motivasi kepada para pegawai agar mereka bersedia dengan iklas melakukan apa yang menjadi kepentingan perusahaan, mengingat apabila kepentingan perusahaan tercapai maka kepentingan individupun juga akan terpenuhi. Tujuan dapat tercapai bila memiliki pegawai yang berkualitas dan memiliki semangat kerja yang tinggi. Untuk dapat memiliki semangat kerja yang tinggi dari para pegawai, maka antara pegawai dan perusahaan harus tercipta suatu hubungan kerja yang bersifat manusiawi, selaras dan harmonis. Dengan adanya hubungan kerja yang bersifat manusiawi, selaras dan harmonis tersebut diharapkan dapat mendorong karyawan perusahaan untuk bekerjan secara produktif.

Guna memacu semangat kerja yang tinggi tentunya tidak terlepas dari peran manajer sumber daya manusia (SDM) dalam mengelola SDM secara optimal dan seimbang dengan sistem, aturan dan nilai yang ada di perusahaan, sehingga karyawan dalam menjalankan fungsi dan jabatannya benar-benar menyukai pekerjaanya dan memandang pekerjaanyan bukan sebagai beban, melainkan sebagai suatu hal yang menyenangkan. Keadaan tersebut sangat penting bagi perusahaan karena semangat kerja yang tinggi akan mengurangi angka absensi atau tidak bekerja karena malas, pekerjaan yang diberikan atau ditugaskan kepadannya akan dapat diselesaikan dalam waktu yang lebih singkat, perusahaan akan mendapatkan keuntungan dilihat dari kecilnya angka kerusakan, kecil kemungkinan karyawan akan pindah bekerja ke tempat lain, dan dapat mengurangi angka kecelakaan karena karyawan yang bersemangat tinggi cenderung bekerja dengan hati-hati dan teliti sesuai prosedur yang ada.

Menurut Nawawi (2010), faktor yang mempengaruhi semangat kerja di dalam perusahaan merupakan lingkungan kerja fisik dimana tempat karyawan tersebut melaksanakan tugas dan pikirannya sehari- hari. lingkungan kerja fisik adalah semua keadaan berbentuk fisik yang terdapat di sekitar tempat kerja yang dapat mempengaruhi karyawan baik secara langsung maupun secara tidak langsung. (Sedarmayanti, 2008). Sedangkan menurut Buchari Zainun (2013) ada beberapa faktor yang mempengaruhi semangat kerja karyawan yaitu: komunikasi yang baik dan hubungan harmonis antara pimpinan dan bawahan terutama antara pemimpinan yang seharihari langsung berhadapan dan berkomunikasi dengan para karyawan yang dibawahinya, kepuasan para karyawan terhadap tugas, pekerjaannya dan mengerjakan tugas dengan tanggung jawab karena atasan yang berkomunikasi secara baik dengan karyawan dalam memberikan tugas, karyawan berada pada 
lingkungan kerja yang sehat dan baik, seperti lingkungan yang tidak kotor, tidak lembab, dan suhu teratur. Rasa turut serta berkontribusi dalam mencapai tujuan organisasi yang juga merupakan tujuan bersama -sama mereka yang harus diwujudkan secara bersama- sama pula. Adanya tingkat kepuasan ekonomi dan kepuasan meteril lainnya sebagai imbalan yang dirasakan adil terhadap jerih payah yang telah diberikan kepada organisasi. Adanya keterangan jiwa jaminan kepastian serta perlindungan terhadap segala sesuatu yang dapat membahayakan diri pribadi dan karir dalam pekerjaan.

Sedangkan menurut Barry Render \& Jay Heizer (2001:239), lingkungan kerja merupakan lingkungan fisik tempat karyawan bekerja yang mempengaruhi kinerja, keamanan dan mutu kehidupan kerja mereka. Lingkungan kerja yang kondusif memberikan rasa aman dan memungkinkan para pegawai untuk dapat bekerja optimal. Lingkungan kerja dapat mempengaruhi emosi pegawai, jika pegawai menyenangi lingkungan kerja dimana ia bekerja, maka pegawai tersebut akan betah di tempat bekerjanya untuk melakukan aktivitas sehingga waktu kerja dipergunakan secara efektif dan optimal prestasi kerja pegawai juga tinggi. Lingkungan kerja tersebut mencakup hubungan kerja yang terbentuk antara sesama pegawai dan hubungan kerja antar bawahan dan atasan serta lingkungan fisik tempat pegawai bekerja. Kesesuaian lingkungan kerja dapat dilihat akibatnya dalam jangka waktu yang lama lebih jauh lagi lingkungan-lingkungan kerja yang kurang baik dapat menuntut tenaga kerja dan waktu yang lebih banyak dan tidak mendukung diperolehnya rancangan sistem kerja yang efisien. Lingkungan kerja fisik terbagi dalam dua dimensi yaitu lingkungan yang langsung berhubungan dengan karyawan indikatornya seperti: tempat pusat kerja, keadaan kursi, meja dan kondisi gedung/bangunan, adalah suasana kekeluargaan, komunikasi yang baik dan pengendalian diri dan Lingkungan perantara atau lingkungan umum dapat juga disebut lingkungan kerja yang mempengaruhi kondisi manusia, (indikatornya seperti: temperatur, kelembaban, sirkulasi udara, pencahayaan, kebisingan, geteran mekanis, bau tidak sedap, warna, dan lain- lain). Untuk dapat memperkecil pengaruh lingkungan fisik terhadap karyawan, maka langkah pertama adalah harus mempelajari manusia, baik mengenai fisik dan tingkat lakunya maupun mengenai fisiknya, kemudian digunakan sebagai dasar memikirkan lingkungan fisik yang sesuai.

Menurut Arep \& hendri (2003), manfaat lingkungan kerja adalah menciptakan gairah kerja, sehingga produktivitas dan prestasi kerja meningkat. Sementara itu, manfaat yang diperoleh karena bekerja dengan orang-orang yang termotivasi adalah pekerjaan dapat terselesaikan dengan tepat, yang artinya pekerjaan diselesaikan sesuai standar yang benar dan dalam skala waktu yagn ditentukan. Prestasi kerjanya akan dipantau oleh individu yang bersangkutan, dan tidak akan menimbulkan terlalu banyak pengawasan serta semangat juangnya akan tinggi. Lingkungan kerja yang baik dan kondusif dapat meningkatkan semangat kerja. Kondisi lingkungan kerja perusahaan seperti kelengkapan alat penunjang pekerjaan, fasilitas kerja yang nyaman, keamanan yang terjamin dan rekan kerja yang dapat bekerja sama dengan baik dapat membuat karyawan bekerja sungguhsungguh dan pekerjaan akan selesai sesuai dengan rencana." Lingkungan kerja merupakan sesuatu yang ada di sekitar perusahaan yang mempengaruhi cara kerja dan produktivitas kerja karyawan" (Nasution, 2013:3). Lingkungan kerja tempat suatu perusahaan berada menjadi faktor eksternal yang mempengaruhi semangat kerja karyawan. Menurut Shindaye et al,(2011) bahwa lingkungan kerja memiliki pengaruh yang dasyat untuk seorang individu, akan memberikan efek yang besar pada apa yang dikerjakan. Kondisi fisik dari suatu lingkungan kerja mempunyai pengaruh besar dalam tingkat semangat kerja karyawan. Organisasi agar dapat mencapai tahap produkitivitas pekerja yang tinggi, perlu memastikan bahwa lingkungan kerja fisik sudah mendukung para karyawan (Leblebici,2012). 
Secara fisik, faktor yang mempengaruhi lingkungan kerja adalah tata ruang kerja, penerangan, gangguan dalam ruang kerja, keadaan udara, warna, kebersihan, dan musik. Lingkungan kerja adalah kehidupan sosial, psikologi, dan fisik dalam perusahaan yang berpengaruh terhadap pekerja dalam melaksanakan tugasnya. Kehidupan manusia tidak terlepas dari berbagai keadaan lingkungan sekitarnya, antara manusia dan lingkungan terdapat hubungan yang sangat erat. Dalam hal ini, manusia akan selalu berusaha untuk beradaptasi dengan berbagai keadaan lingkungan sekitarnya. Demikian pula halnya ketika melakukan pekerjaan, karyawan sebagai manusia tidak dapat dipisahkan dari berbagai keadaan disekitar tempat mereka bekerja, yaitu lingkungan kerja. Selama melakukan pekerjaan, setiap pegawai akan berinteraksi dengan berbagai kondisi yang terdapat dalam lingkungan kerja. Indikator yang digunakan pada kondisi lingkungan kerja fisik di PT.Bali Maya Permai Negara secara umum masih kurang memadai dimana terlihat pada ruang kerja pimpinan yang sangat sempit dan hampir dijejal oleh meja staf karyawan. Selain itu kurangnya kebersihan yang terlihat pada banyaknya limbah sisa pengolahan ikan sehingga menimbulkan bau yang menyengat di sekitar lingkungan kerja, dan juga ruang kerja yang panas. Kondisi tersebut dapat menurunkan semangat karyawan dalam menyelesaikan tugas-tugasnya dengan baik. Rendahnya semangat kerja dapat mengakibatkan tingginya tingkat kesalahan dan penyelesaian tugas memakan waktu yang lebih lama. Selain lingkungan kerja fisik, dan faktor lain yang mempengaruhi semangat kerja karyawan adalah komunikasi, Setianingsih (2010) menyatakan bahwa, komunikasi berpengaruh pada tingkat semangat kerja karyawan. Komunikasi internal menjadi salah satu faktor pendorong karyawan untuk bekerja dengan sungguh-sungguh, serta kompensasi menjadi daya tarik bagi karyawan agar pekerjaannya terselesaikan dengan cepat. Komunikasi yang kurang efektif tercermin dalam sikap konsistensi dari atasan yang menyebabkan program kerja yang ingin dicapai tidak terkoordinasi dengan baik.

Selain lingkungan kerja fisik, faktor lain yang mempengaruhi semangat kerja karyawan adalah komunikasi. Komunikasi merupakan hal yang sangat penting di dalam organisasi, karena komunikasi berlaku sebagai rantai koordinasi antara karyawan dengan fungsi organisai. Setianingsih (2010) menyatakan bahwa, komunikasi berpengaruh pada tingkat semangat kerja karyawan. Komunikasi internal menjadi salah satu faktor pendorong karyawan untuk bekerja dengan sungguh-sungguh, serta kompensasi menjadi daya tarik bagi karyawan agar pekerjaannya terselesaikan dengan cepat. Komunikasi yang kurang efektif tercermin dalam sikap konsistensi dari atasan yang menyebabkan program kerja yang ingin dicapai tidak terkoordinasi dengan baik. Komunikasi merupakan hal yang sangat penting di dalam organisasi, karena komunikasi berlaku sebagai rantai koordinasi antara karyawan dengan fungsi organisai. Menurut robbins dan Coulter (2004) menyatakan pengertian komunikasi itu adalah penyampaian dan pemahaman suatu maksud yang perlu diperhatikan dalam definisi ini adalah penakanannya pada penyampaian maksud, komunikas tak akan perna terjadi tanpa pemahaman maksud komunikasi jarang berhasil informasi dari seseorang kepada orang lain dengan harapan timbul kesamaan pengertian dan persepsi yang kemudian diarahkan kepada suatu tindakan untuk mencapai tujuan yang telah ditetapkan. Sedangkan Supradi (2009:89) menyatakan bahwa " komunikasi adalah dikehendaki oleh orang yang mempunyai pendapat tersebut, sehingga diharapkan diperoleh titik kesamaan saling pengertian. Untuk menunjang proses komunikasi, pemimpin memerlukan sarana dan perasanan dimana pemimpin harus mampu menjadi komunikasi yang bisa mengolah suatu informasi dan menciptakan cara penyampaian informasi tersebut. Dalam hal ini, informasi yang dimaksud adalah informasi yang berpengaruh terhadap semangat kerja karyawan sehingga 
informasi itu mudah dimengerti dan diterima.

Diketahui dalam perusahaan PT. Bali Maya Permai Negara untuk kondisi komunikasi vertikal, terdapat permasalahan pengarahan dari pimpinan perusahaan mengenai mekanisme kerja yang masih kurang efektif sehingga karyawan cenderung melaksanakan pekerjaan sesuai dengan persepsinnya sendiri, serta pembagian tugas dan pelimpahan wewenang masih belum dapat dikomunikasikan dengan baik oleh pimpinan kepada karyawan PT. Bali Maya Permai Negara. Selain itu, diketahui kurangnya keakraban atau ramah tamah antara karyawan dengan karyawan lain selama jam kerja, sehingga hal tersebut berdampak pada semangat kerja karyawan PT. Bali Maya Permai Negara.

Kondisi semangat kerja karyawan PT.Bali Maya Permai sangat rendah. Hal tersebut dapat dilihat dari tingkat disiplin karyawan yang rendah, tingkat absensi yang masih tinggi, kurangnya keakraban antar karyawan dan atasan sehingga mempengaruhi kualitas kerjasama, serta kurangnya kepuasan karyawan terhadap jaminan yang diberikan atasan seperti rewards atau bonus bagi pekerja yang pekerjaanya baik dan memuaskan dan tidak ada jaminan asuransi bagi karyawan dari perusahaan, berdasarkan data absensi karyawan dari 55 orang karyawan jumlah absen karyawan dalam satu hari 5 sampai 7 orang, sedangkan dijumlahkan dalam satu bulan terdapat 24 karyawan yang absen, hal ini mempengaruhi ketepatan dalam menyelesaikan pekerjaannya. Karyawan yang harusnya datang ke gudang pada jam 09.00 pagi, tapi datang lebih dari jam 09.00 pagi. Sehingga hal tersebut mengurangi jam kerja karyawan. Setelah ditinjau , ternyata semangat karyawan yang rendah dalam bekerja di sebabkan oleh kurangnya ramah tamah dari sesama karyawan dan dari atasan terhadap karyawan, sehingga tidak ada keakraban dan hubungan kerja yang baik dalam perusahaan PT.Bali Maya Permai Negara-Jembrana.

Berdasarkan data yang didapat dari hasil observasi awal yang dipaparkan di latar belakang maka Adapun tujuan penelitian ini adalah untuk mengetahui halhal sebagai berikut. Pertama Pengaruh lingkungan kerja fisik terhadap semangat kerja karyawan PT.Bali Maya Permai Negara, jembrana. Kedua Pengaruh komunikasi terhadap semangat kerja karyawan PT.Bali Maya Permai NegaraJembrana. Ketiga Pengaruh lingkungan kerja fisik dan komunikasi secara simultan terhadap semangat kerja karyawan PT.Bali Maya Permai Negara-Jembrana.

\section{METODE}

Penelitian ini dilakukan di PT.Bali Maya Permai Negara untuk mengetahui pengaruh lingkungan kerja fisik dan komunikasi terhadap semangat kerja karyawan. Penelitian ini menggunakan desain penelitian kausal yang digunakan untuk memperoleh eksplanasi yang teruji mengenai a) pengaruh lingkungan kerja (X1) terhadap semangat kerja karyawan PT. Bali Maya Permai (Y), b) pengaruh komunikasi (X2) terhadap semangat kerja karyawan PT. Bali Maya Permai (Y), dan C) pengaruh lingkungan kerja (X1) dan komunikasi (X2) terhadap semangat kerja karyawan PT. Bali Maya Permai (Y). Adapun rancangan penelitian ini adalah mengacu pada kerangka pemikiran yang sudah dijelaskan sebelumnya.

Populasi yang digunakan dalam penelitian ini adalah seluruh karyawan di PT.Bali Maya Permai Negara, yang beralamat di Desa Cupel, NegaraJembrana. , yaitu sebanyak 33 orang. Menurut Arikunto (2002), apabila populasi kurang dari 100, lebih baik diambil semua sehingga penelitiannya merupakan penelitian populasi.

Berdasarkan jenisnya, data yang digunakan dalam penelitian ini adalah data kuantitatif. Data kuantitatif, data yang berbentuk angka-angka hasil dari pengukuran lingkungan kerja fisik, komunikasi, dan semangat kerja karyawan. Data kuantitatif dalam penelitian ini berupa data yang diperoleh dari responden (karyawan) di PT.Bali Maya Permai Negara, yang beralamat di Desa Cupel, NegaraJembrana.

Berdasarkan sumbernya, sumber data yang digunakan dalam penelitian ini adalah data primer. Data primer dalam penelitian 
ini yaitu skor hasil kuesioner. Metode pengumpulan data dalam penelitian ini adalah kuisioner dan dokumentasi. Metode kuisioner ini ditujukan kepada seluruh karyawan perusahaan yang berjumlah 55 orang untuk memperoleh data tentang lingkungan kerja fisik, komunikasi, dan semangat kerja karyawan. Metode dokumentasi digunakan untuk mengumpulkan data nama-nama karyawan di PT. Bali Maya Permai, presensi atau tingkat ketidak hadiran karyawan dan peningkatan atau penurunan produktivitas dalam bekerja untuk mengukur semangat karyawan.

\section{HASIL DAN PEMBAHASAN \\ Hasil}

Pengaruh Lingkungan Kerja Fisik Fisik dan komunikasi Terhadap Semangat Kerja Karyawan Pada PT Bali Maya Permai Negara, jembrana dilihat pada tabel 1 sebagai berikut.

Tabel 1. Hasil Uji t untuk Variabel Lingkungan kerja Fisik

\begin{tabular}{|c|c|c|c|c|c|}
\hline \multirow[b]{2}{*}{ Model } & \multicolumn{2}{|c|}{$\begin{array}{l}\text { Unstandardized } \\
\text { Coefficients }\end{array}$} & \multirow{2}{*}{$\begin{array}{c}\begin{array}{c}\text { Standardized } \\
\text { Coefficients }\end{array} \\
\text { Beta }\end{array}$} & \multirow[b]{2}{*}{$\mathrm{t}$} & \multirow[b]{2}{*}{ Sig. } \\
\hline & $\mathrm{B}$ & Std Error & & & \\
\hline 1(Constant) & -663 & 2,078 & & -319 & .751 \\
\hline $\begin{array}{l}\text { Lingkungan } \\
\text { kerja Fisik }\end{array}$ & 579 & , 090 & .641 & 6.447 & .000 \\
\hline
\end{tabular}

Berdasarkan tabel 1 menunjukkan bahwa variabel lingkungan kerja fisik berpengaruh signifikan terhadap semangat kerja karyawan, karena nilai $t_{\text {titung }}=6,447>t_{\text {tabel }}=0,2609$ atau $p$ - value $=$ $0,018<\mathrm{a}=0.05$ maka Ho ditolak. Oleh karena itu, maka dapat disimpulkan bahwa variabel lingkungan kerja fisik memiliki

pengaruh yang signifikan terhadap semangat kerja karyawan pada PT bali maya permai negara - jembrana.

Pengaruh Komunikasi Karyawan Terhadap Semangat Kerja Karyawan Pada PT Bali Maya Permai Negara - Jembrana dapat dilihat pada tabel 2 .

Tabel 2. Hasil Uji t untuk Variabel Komunikasi karyawan

\begin{tabular}{llllll}
\hline Model & \multicolumn{2}{c}{$\begin{array}{c}\text { Unstandardized } \\
\text { Coefficients }\end{array}$} & $\begin{array}{l}\text { Standardized } \\
\text { Coefficients }\end{array}$ & \multirow{2}{*}{ Sig } \\
\cline { 2 - 4 } & $\mathrm{B}$ & Std. Error & Beta & & \\
\hline 1 (Constant) & -663 & 2.078 & & -319 & -751 \\
Komunikasi & & & & &
\end{tabular}

Berdasarkan tabel. 2. menunjukkan bahwa variabel komunikasi karyawan berpengaruh signifikan terhadap semangat kerja, karena nilai $t_{\text {hitung }}=2,448$ $>t_{\text {tabel }}=0.609$ atau $p$ - value $=0.000<a=$ 0.05 maka Ho ditolak. Oleh karena itu, maka dapat disimpulkan bahwa variabel komunikasi karyawan berpengaruh secara
2.43

$2,448 \quad 081$

signifikan terhadap semangat kerja karyawan pada PT bali maya permai negara - jembrana

Pengaruh Lingkungan Kerja Fisik dan Komunikasi Karyawan Terhadap Semangat Kerja Karyawan Pada PT Bali Maya Permai Negara - Jembrana dapat dilihat pada tabel 3 . 
Tabel 3. Hasil Perhitungan Uji F

\begin{tabular}{llllll}
\hline Model & $\begin{array}{l}\text { Sum of } \\
\text { Squares }\end{array}$ & Df & $\begin{array}{l}\text { Mean } \\
\text { Square }\end{array}$ & $\mathrm{F}$ & \multirow{2}{*}{ Sig } \\
\cline { 1 - 4 } 1 Regression & 926.478 & 2 & 462.239 & 48.516 & \\
Residual & 410.311 & 42 & 9.770 & & \\
Total & 1336.789 & 44 & & &
\end{tabular}

Berdasarkan tabel. 3. menunjukkan bahwa $F_{\text {hitung }}=48.516>F_{\text {tabel }} 3.22$ atau $p$ value $=0,000<a=0,05$ hal ini berarti Ho ditolak. Oleh karena itu, maka dapat disimpulkan bahwa variabel lingkungan kerja fisik dan komunikasi karyawan memiliki pengaruh yang signifikan terhadap variabel semangat kerja karyawan
PT Bali Maya Permai Negara - Jembrana. Untuk mengetahui besarnya pengaruh lingkungan kerja fisik dan komunikasi terhadap semangat kerja karyawan, maka dapat digunakan analisis koafisien determinasi ( Adjusted $R$ Square). Besarnya koefisien determinasi (Adjusted $R$ Square) dapat dilihat pada tabel 4 .

Tabel 4. Hasil Perhitungan Koefisien Determinasi

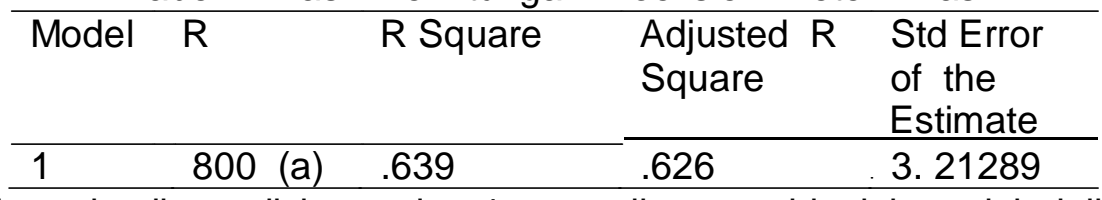

Berdasarkan hasil analisis pada 4 dipengaruhi oleh variabel lingkungan kerja dengan menggunakan program SPSS 16.0 for windows menunjukkan bahwa besarnya pengaruh variabel lingkungan kerja fisik dan komunikasi karyawan terhadap variabel semangat kerja adalah sebesar 0.626 sehingga sumbangan pengaruh untuk variabel lingkungan kerja fisik ( X1) dan Komunikasi karyawan (X2) terhadap semangat kerja ( $Y$ ) adalah sebesar $62,6 \%$. Hal ini berarti semangat kerja karyawan Pada PT Bali Maya Permai Negara - Jembrana sebesar 62,6\% fisik dan komunikasi karyawan, sedangkan sisanya sebesar $32,2 \%$ dipengaruhi oleh faktor lain yang tidak termasuk dalam penelitian ini.

Berdasarkan hasil analisis data, persamaan garis regresi lingkungan kerja fisik dan komunikasi karyawan terhadap semangat kerja pada PT Bali Maya Permai Negara -Jembrana digunakan nilai Unstandardized Coefficients Beta dapat dilihat pada tabel 5.

Tabel 5. Hasil Perhitungan Koefisien Beta

\begin{tabular}{|c|c|c|c|c|c|}
\hline \multirow[t]{2}{*}{ Model } & \multicolumn{2}{|c|}{$\begin{array}{l}\text { Unstandardized } \\
\text { Coefficients }\end{array}$} & \multirow{2}{*}{$\begin{array}{l}\text { Standardized } \\
\text { Coefficients } \\
\text { Beta }\end{array}$} & \multirow[b]{2}{*}{$\mathrm{t}$} & \multirow[b]{2}{*}{ Sig. } \\
\hline & $B$ & Std Error & & & \\
\hline 1 (Constant) & -663 & 2,078 & & -319 & .751 \\
\hline $\begin{array}{l}\text { Lingkungan } \\
\text { kerja fisik } \\
\text { Komunikasi }\end{array}$ & 461 & 188 & 243 & 2.448 & 018 \\
\hline karyawan & 579 & 090 & 6.41 & 6.447 & .000 \\
\hline
\end{tabular}


Berdasarkan analisis pada tabel 5 dengan mengunakan program SPSS 16.0 for windows dapat dibuat persamaan garis regresi. Persamaan garis regresi yang dapat dibuat untuk menggambarkan pengaruh lingkungan kerja fisik dan komunikasi karyawan terhadap semangat kerja karyawan PT. Bali maya Permai Negara adalah sebagai berikut.

$\hat{Y}=-663+0.461 X_{1}+0.579 X_{2}$

Keterangan

$\hat{Y}=$ semangat kerja

$\mathrm{X}_{1}=$ Lingkungan kerja Fisik

$\mathrm{X}_{2}=$ Komunikasi

Interpretasi dari model regresi di atas yaitu konstanta - 663 menunjukkan bahwa jika variabel bebas lingkungan kerja fisik (X1) dan komunikasi (X2) sama dengan nol, maka semangat kerja ( Y) akan mengalami kenaikan sebasar 663 satuan. Koefisien regresi 0.461 berarti jika variabel lingkungan kerja fisik (X1) meningkat tiap satu satuan, maka semangat kerja (Y) akan mengalami peningkatan sebesar .0 .461 dengan syarat variabel bebes lainnya tetap. Koefisien regresi 0.579 berarti jika variabel komunikasi (X2) meningkat tiap satu satuan, maka semangat kerja (Y) akan mengalami peningkatan sebesar 0.579 dengan syarat variabel bebas lainnya tetap.

Berdasarkan persamaan regresi linier berganda yang dihasilkan, dapat ditunjukkan bahwa lingkungan kerja dan komunikasi berpengaruh positif terhadap semangat kerja karyawan PT. Bali Maya Permai Negara Jembrana.

\section{PEMBAHASAN}

Berdasarkan hasil analisis deskriptif yang telah dilakukan, maka dapat diketahui bahwa lingkungan kerja fisik dan komunikasi berada dalam katagori sedang dengan rentangan skor masingmasing pada lingkungan kerja fisik 936715 dan komunikasi 949- 527 Sedangkan semangat kerja berada dalam katagori rendah dengan rentangan skor 1145- 792. Nilai $F_{\text {hitung }}=48.516>F_{\text {tabel }} 3.22$ atau $p$ value $=0,000<\mathrm{a}=0,05$ hal ini berarti Ho ditolak. Oleh karena itu, maka dapat disimpulkan bahwa variabel lingkungan kerja fisik dan komunikasi karyawan memiliki pengaruh yang signifikan terhadap variabel semangat kerja karyawan PT Bali Maya Permai Negara, jembrana.

Temuan hasil penelitian ini juga sejalan dengan temuan penelitian yang dilakukan oleh Ariesto (2010) yang mengungkapkan rendahnya semangat kerja disebabkan karena para pegawai merasa belum terpenuhi dalam hal perlengkapan dan fasilitas, kebersihan dan musik, sedangkan hasil penelitian komunikasi organisasi terutama komunikasi keatas, para pegawai merasa tidak mendapat tanggapan saat menyampaikan keluhan atau pun pendapat.

Hasil temuan ini menunjukkan bahwa lingkungan kerja fisik dan komunikasi berpengaruh terhadap semangat kerja karyawan. Hasil temuan penelitian ini sejalan atau mendukung pernyataan dari Gorda ( 2004:13) yang menyatakan bahwa yang mempengaruhi semangat kerja karyawan adalah lingkungan kerja dan komunikasi. Temuan hasil penelitian ini juga mendukung temuan penelitian yang dilakukan oleh Tigor ( 2011), yang mengungkapkan bahwa lingkungan kerja dan komunikasi berpengaruh positif dan signifikan terhadap semangat kerja karyawan pada Apotik kimia Farma di Bali.

Hasil analisis regresi menunjukkan bahwa pengaruh yang positif dan signifikan dari lingkungan kerja karyawan terhadap semangat kerja. Temuan hasil penelitian yang dilakukan oleh Denok (2008), menyatakan bahwa pada pengaruh positif dan signifikan lingkungan kerja terhadap semangat kerja karyawan pada PT Bali Maya Permai Negara- Jembrana.

Hasil analisis regresi menunjukkan bahwa ada pengaruh yang positif dan signifikan dari komunikasi terhadap semangat kerja. Temuan hasil penelitian ini sejalan dengan penelitian yang oleh Dimas Prayogi (2010). yang menyatakan bahwa ada pengaruh positif dan signifikan komunikasi terhadap semangat kerja karyawan pada PT Telkom Regional Customer 


\section{SIMPULAN DAN SARAN Simpulan}

Berdasarkan hasil penelitian dan pembahasan yang telah diuraikan, maka dapat dibuat simpulan sebagai berikut: Ada pengaruh dan signifikan secara parsial dari lingkungan kerja fisik terhadap semangat kerja karyawan pada PT Bali Maya Permai Negara, jembrana. Temuan ini mengindikasikan secara parsial lingkungan kerja fisik berperan dalam mendukung semangat kerja karyawan pada PT Bali Maya Permai NegaraJembrana. Ada pengaruh positif dan signifikan secara parsial dari komunikasi terhadap semangat kerja PT Bali Maya Permai Negara- Jembrana. Temuan ini mengindikasikan secara parsial komunikasi berperan dalam mendukung semangat kerja karyawan pada PT Bali Maya Permai Negara- Jembrana. Ada pengaruh positif dan signifikan secara simultan pada lingkungan kerja fisik dan komunikasi karyawan terhadap semangat kerja karyawan pada PT Bali Maya Permai Negara- Jembrana. Temuan ini memberikan implikasi bahwa lingkungan kerja fisik dan komunikasi berperan dalam mendukung semangat kerja karyawan pada PT Bali Maya Permai Negara, jembrana.

\section{Saran}

Berdasarkan simpulan di atas, maka penulis mengajukan saran-saran sebagai berikut: Bagi perusahaan disarankan untuk meningkatkan semangat kerja dengan meningkatkan kondisi lingkungan kerja fisik dari segi keadaan suhu udara yang tinggi pada ruangan kerja, dengan memberikan AC ( air condition) atau kipas angin pada setiap ruangan kerja untuk mengurangi keadaan suhu udara yang panas dalam ruangan, serta meningkatkan komunikasi dengan meningkatkan diskusi - diskusi melalui forum formal dan informal. Bagi peneliti selanjutnya diharapkan dapat mengembangkan penelitian selanjutnya dengan topik yang sama tetapi mempertimbangkan variabel lain yang dapat mempengaruhi semangat kerja karyawan.

\section{DAFTAR PUSTAKA}

Arep , I \& Tanjung, Hendri. 2003. Manajemen Sumber Daya Menusia Jakarta : Universitasitas Tri Sakti

Ariesto. 2010. Pengaruh Pelaksanaan Komunikasi, Lingkungan Kerja,Dan Penembangan Pegawai Terhadap Semangat Kerja Pegawai. Tersedia pada http:// soalkerja. Blogspot.com/2010/01 skripsipengaruh- pelaksanaan -komunikasi. $\mathrm{Html}$. (diakses tanggal 8 Oktober 2012).

Arikunto, Suharsimi . 2002. Manajemen Penelitian . Jakarta : Rineka Cipta.

Buchari Zainun. 2013. Manajemen Dan Komunikasi, Jakarta: Balai Pustaka.

Coulter, Robbins. 2004. Manajemen Edisi Ketujuh, Edisi Indonesia Jilid Kesatuan Jakarta PT Indeks Group Gramedia

Gorda, I Gusti Ngurah. 2004. Manajemen Sumber Daya Manusia. Jakarta: PT.Indeks

Leliyana, Datok. 2008. Pengaruh FaktorFaktor Lingkungan Kerja Terhadap Semangat Kerja Karyawan Kantor Pelayanan Pajak Surabaya Gudang Tesis. (Tidak terbitkan) Universitas airlangga.

Leblebici D. 2012. Impact Of Workplace Quality On Employee' Productivity Core Study Of .A Banking Turkey. Jurnal Of Business Ekonomics And Finance, Vo.L

Render Barry \& Heizer Jay. 200. Prinsi Prisip Manajemen Operasi Edisi Jakarta : selemba. Empat

Prayogi, Dimas. 2010. Pengaruh Komunikasi Terhadap Semangat Kerja Karyawan Pada PT Telkom Regional / Sumatra Bidang Customer Care Medan. Skripsi (Tidak Diterbitkan.) Jurusan Manajemen, Fakultas Ekonomi, Universitas Sumatera 
p-ISSN : 2599-1418

e-ISSN : 2599-1426
Jurnal Pendidikan Ekonomi Undiksha Volume 10 No. 1 Tahun 2018

Serdamayanti, dkk. 2008. Sumber Daya Manusia Dan Produktivitas Kerja Mandar Maju Bandung: Alfa beta.

Setianingsih. 2010. Pengaruh Kompensasi Dan Komunikasi Internal Terhadap Semangat Kerja Karyawan Pada Koperasi," SAF Desa Rujon Lor Kecamatan Malang. Jurnal Ekslusif Volume 3.

Shidhaye RV, dkk .2011. Influence Of Warking Condition On Job Sarisfaction Indian Anesthesiologists: A Cross Sectional Survey Indian Institute Of Public Health Jurnal.

Surpadi , \& Saiful Anwar. 2009. Prosedur Penelitian Suatu Pendekatan Praktek, Edisi Revisi. Jakarta :Rineka Cipta

Tigor, S.2009. Kebisingan di Tempat Kerja. Yogyakarta: Sinar Jaya. 